\title{
Can Li-Ion Batteries be the Panacea for Automotive Applications?
}

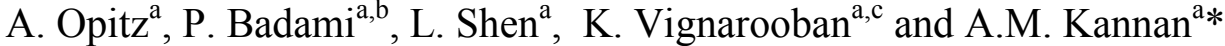 \\ ${ }^{a}$ The Polytechnic School, Ira A. Fulton Schools of Engineering, Arizona State University, Mesa, \\ AZ 85212, USA \\ ${ }^{\mathrm{b}}$ School for Engineering of Matter, Transport and Energy, Ira A. Fulton Schools of \\ Engineering, Arizona State University, Tempe, AZ 85287, USA \\ ${ }^{c}$ Department of Physics, Faculty of Science, University of Jaffna, Jaffna 40000, Sri Lanka
}

\begin{abstract}
The fuel economy of 31 MPG (based on combined city and highway) and Environment labels are being affixed to new vehicles after 2013 model year, as mandated by the U.S. Environmental Protection Agency. Most of the fuel-efficient 2016 model year passenger cars are hybrid electric vehicles. Hybrids combine the best features of the internal combustion engine with an electric motor powered by batteries and can significantly improve fuel economy. Plug-in hybrids are plugged into wall outlet for battery recharging or driven by electric motor for relatively longer distance. The all-electric vehicles are propelled by electric motor powered using rechargeable battery packs, emitting no tailpipe pollutants. Among various battery technologies, Li-ion battery system is the more preferable one for the automotive applications due to their relatively higher energy density. This review examines various aspects of $\mathrm{Li}$-ion batteries related to performance, durability, energy management and safety related to automotive applications. The review also discusses about the possibility of automotive Li-Ion batteries towards second life in stationary applications.
\end{abstract}

Keywords: Li-ion Batteries; Electric vehicles; Safety; Cycle life; Capacity fading; After-life

* Corresponding author. Tel.: +1 (480) 727-1102; Fax: +1 (480) 727-1549

E-mail: amk@asu.edu (A.M. Kannan) 


\section{Table of Contents}

ABSTRACT

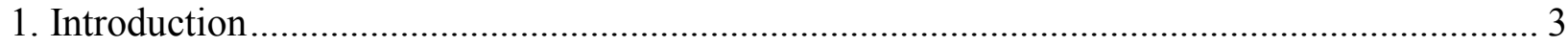

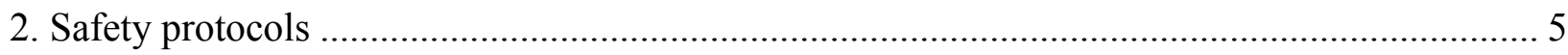

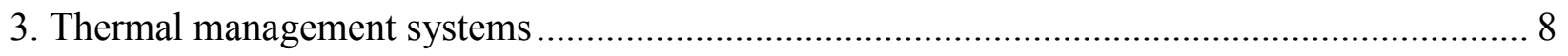

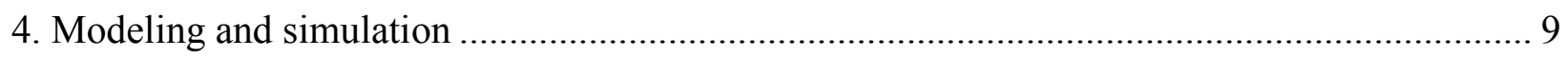

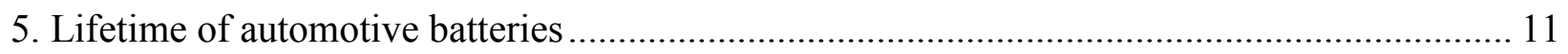

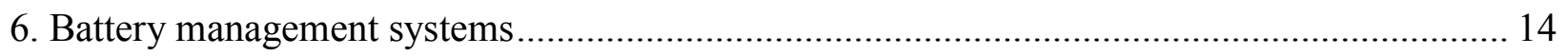

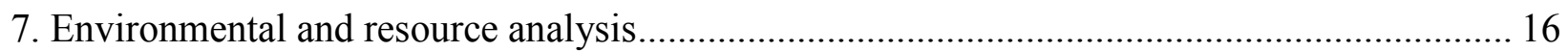

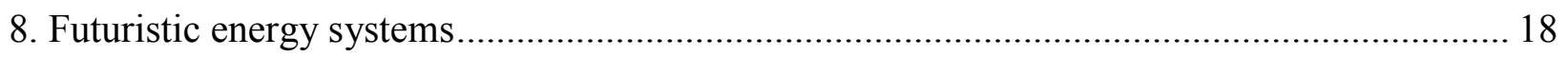

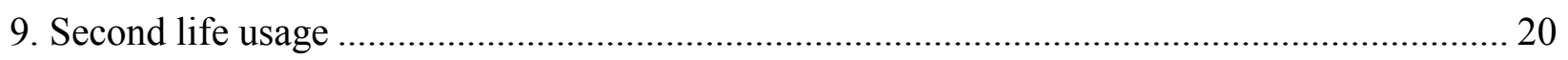

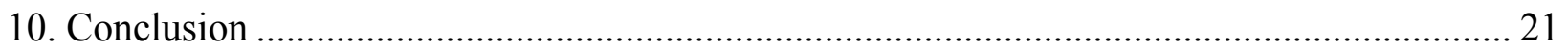

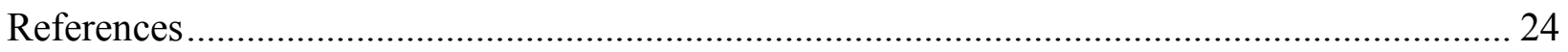




\section{Introduction}

There are many variants being offered in the vehicle market including micro hybrids, mild hybrids, plug-in hybrids (PHEVs) and all-electric vehicles (EVs) with battery systems. A micro hybrid vehicle is a system that has the start-stop technology. This allows the vehicle to be started by the battery pack, capture energy to be stored into the battery while braking, and the ability to support the electrical systems when the internal combustion engine (ICE) is shut off. The mild hybrid has same features as that of micro hybrid along with some additional features. These features are an electric motor/generator in parallel with the ICE, which can assist when the vehicle is coasting, braking or stopped. Although the mild hybrid can assist combustion engine, there is no electric-only mode of driving. PHEV has the same features of the mild hybrid vehicles with the ability to plug into the electrical grid as well as having an electric-only mode of driving. PHEV performance is strongly influenced by powertrain architecture and is classified into input split, parallel, series, series-output split and series-parallel. Series configuration has higher efficiency in EV mode, but lower efficiency in hybrid mode due to losses in electric motor and the parallel configuration has higher efficiency compared to series architecture due to lower losses in electric motor [1]. Figure 1 shows the schematic of series and parallel hybrid powertrains. The series configuration consists of generator and motor and the traction is only provided through motor. Motor receives power either through battery pack or generator operated by ICE $[2,3]$. In the case of parallel architecture, traction is provided by ICE or battery pack in tandem arrangement while batteries are recharged through motor/generator during coasting and braking. An all-electric vehicle runs solely on the battery system powering the motor. The hybrid and electric vehicle markets are being driven by a number of factors such as consumer interest, technology, cost, regulatory requirements and a variety of government incentives. These factors 
are influenced by battery system characteristics such as cell chemistry, energy density, power density, cycle life as well as operating conditions.

The type of chemistry is extremely important as it dictates inherent safety, shelf life, battery design and so on. Among various battery systems, $\mathrm{Pb}$-acid batteries are relatively less expensive among existing automotive battery systems, they use toxic materials and exhibit lowest energy density [4]. Ni-Cd batteries on the other hand show higher energy and power density values compared to $\mathrm{Pb}$-acid batteries, but the electrode materials are toxic ( $\mathrm{Cd}$ anode) and expensive. Although Ni-MH batteries are better compared to Ni-Cd batteries in terms of energy and power densities with environmentally friendly $\mathrm{MH}$ anode, the self-discharge is higher and require complex charging protocols. LIBs are relatively more expensive than other cell chemistries, but they provide the highest energy and power densities as well as longer cycle life and have the ability to incorporate smart battery management systems. Figure 2 shows the specific energy dependence of specific power with the driving range (per charge) of different cell chemistries along with price range per kWh [4]. As indicated in Figure 2, the driving range target would be 350 miles per charge by 2020 to take on the ICEs. LIBs perform relatively well in all the possible variants (Figure 3) and the additional costs can be overlooked [4].

\footnotetext{
The major focus of this review is to bring out the salient features of LIBs based on performance, cycle life, safety aspects to assess if they can be a cure all for automotive applications. In addition, the possibility of using the retired automotive batteries for any stationary applications (second life) is also discussed.
} 


\section{Safety protocols}

Safety has always been a paramount factor when developing and testing the battery system for consumer applications in automobiles. As of late, there are safety experiments being carried out by researchers, organizations, and automakers to ensure safety of battery systems, but there are no unified standards. There might not be standards for battery chemistry because organizations base their standards only on a particular battery chemistry or application. For this reason, there should be a priority to establish a unified standard for automotive batteries, so that the performance and safety could be improved. One possible solution to this problem could be creating an international agency or adding authority to an existing agency to regulate automotive batteries. Another possible solution is to have pre-existing organizations form into a council that governs over a collaborated set of regulations. Possible candidates for the council could be the Society of Automotive Engineers, European Norm and the ISO 9000 standards. Further debate should be conducted for the hypothetical structure of universal automotive standards.

The main safety tests that are being carried out on automotive batteries are analogous to stationary and portable batteries. These tests are most likely being done because regardless of the chemistry or application, batteries share a fundamental set of characteristics. The differences in battery evaluation only occur due to the application and battery chemistry in which diverse tolerances are allowed. In a recent publication on "Are Lithium Ion Cells Intrinsically Safe?" and also in another paper by the same group, the batteries have been evaluated for mining applications under harsh conditions similar to that an automotive battery could possibly experience $[5,6]$. The experiment had two set-ups with one using the UL Standard 1642 and the other being a modified version of the UL 1642 with a $90^{\circ}$ plastic wedge. Additionally, the set-up 
has a controlled atmosphere with moderate level of methane in a temperature range $25-40{ }^{\circ} \mathrm{C}$. The safety tests revealed that the A123 $26650\left(\mathrm{LiFePO}_{4}\right)$ cell was a safer design compared to LG Chem ICR18650S2 $\left(\mathrm{LiCoO}_{2}\right)$. Results also demonstrated that $\mathrm{LiFePO}_{4}$ can withstand physical abuse without causing any safety hazards, while $\mathrm{LiCoO}_{2}$ generated instantaneous fire. As far as safety requirements are concerned, A123 26650 battery with $\mathrm{LiFePO}_{4}$ cathode can be seen as a good choice for automotive applications.

Zaghib et al.[7] studied the safety and performance of the cylindrical battery chemistry of $\mathrm{LiFePO}_{4}, \mathrm{LiMn}_{2} \mathrm{O}_{4}$, and $\mathrm{LiNi}_{0.8} \mathrm{Co}_{0.15} \mathrm{Al}_{0.05} \mathrm{O}_{2}$ to identify the best cell design. The batteries used in this experiment could be possible candidates for being used in EVs, because they could provide the possible performance needed for automotive applications. One part of the experiment was to test the capacity loss after cycling at low and high C-rates while observing the heat generation during charging and discharging of the batteries. Furthermore, a crush and nail penetration test was also done on all of the battery chemistries mentioned above to examine thermal runaway and, if any internal short-circuit was produced. It is interesting to note that $\mathrm{LiFePO}_{4}$ provided outstanding safety and good electrochemical performances, while the other chemistries are relatively unsafe except $\mathrm{LTO} / \mathrm{LiCoO}_{2}$ (see Figure 4). From an overall quality standpoint, it appears that $\mathrm{LiFePO}_{4}$ cathode provides comparable characteristics as other lithium chemistries, and leads superior safety in hazardous situations. Hence, $\mathrm{LiFePO}_{4}$ would most likely be the best choice in designing a battery pack for an automotive application. There are several studies on the design and safety of battery chemistries and how well they perform in extreme situations [2-5]. Experiments under real time operating conditions can be an important 
way to understand the failures of a battery system, but a real world situation may shed light on every type of battery failure that an experimental test could not find.

Recently, a Tesla model S reached an unfortunate accident in Norway in which the electric car exploded and burst into flames [8]. There have been speculations that the explosion was caused by the overcharging of the lithium cells when the car was parked on the supercharging station. There was no evidence released on the actual cause of the accident, but there has been a history of accidents for the model S due to crashes and charging. In another incident, the Chevy Volt caught fire when the vehicle was going through a crash test in late 2011 [9]. This incident made consumers concerned on the safety of the EV even though there are not any greater risks compared to ICEs. This mishap was valuable to show real life effects when battery technology was possibly mistreated. It is essential for automakers to design a battery system that would protect from a possible overcharging situation and to design a system to reduce such extreme situations to protect society.

Battery fires are extreme circumstances in which conventional methods of dousing the fire with water is ineffective because of the specific battery chemistry and its chemical reactions. To extinguish the battery fire in the Tesla model $\mathrm{S}$ incident, an expensive source of foam laced with a copper material would have been required. This retardant would not be economical to produce in large scale. Besides the intense fire from the accident, the smoke emanated from the batteries produced a toxic fluorine gas along with other toxic gases. Additionally, this incident also showed that, it is important to design a safe battery pack that does not pollute the environment. This is a perfect example on why there should be a universal safety protocols for automotive 
batteries and the emphasis people should put on testing the chemistry of different batteries [10].

LIBs with $\mathrm{LTO}$ and $\mathrm{LiFePO}_{4} / \mathrm{LiCoO}_{2}$ show higher safety and better thermal stability compared to other chemistries as shown in Figure 4. Proper thermal management system has to be in place for ensuring safety of the battery system during fast charging as well during any accidents.

\section{Thermal management systems}

The temperature profile of the battery pack plays a crucial role in terms of the performance and the safety for automotive applications. As discussed in section 2, there have been incidents of EVs going into flame due to battery issues $[11,12]$. However, fire accidents are more likely in ICEs compared to EVs. He et al. [13] carried out an investigation on thermal management of A123 26650 battery pack, which was arranged with two cells in parallel and four cells in series. This battery pack was subjected to a forced convection cooling with varying air streams of flow rates $0,1,2.5$ and $5 \mathrm{~m} / \mathrm{s}$, respectively. While being cooled by different flow rates, the batteries were subjected to $1.5 \mathrm{C}$ discharge producing a current of $3.45 \mathrm{~A}$. The results of the experiment were recorded as well as numerically simulated using commercial CFD software. A validated numerical model was utilized to study the power consumption by thermal management system. It has been found that the non-uniformity in cell temperature be dominant at downstream cells compared to the upstream cells for flow rates of 1 and $2.5 \mathrm{~m} / \mathrm{s}$. With increase in wall distance from 5 to $17 \mathrm{~mm}$, there was an average drop of $0.4{ }^{\circ} \mathrm{C}$ per cell for the same flow rate of air. A novel cooling technique using mini-channels surrounding cylindrical cells were numerically studied at $5 \mathrm{C}$ rate for the battery held at $25{ }^{\circ} \mathrm{C}$ [14]. The mass flow rate was held constant throughout the channel with inlets at the anode and outlets at the cathode. Temperature gradients inside the cell with a liquid cooled cylinder were much lower compared to natural convection or no cooling technique. These comparisons were done while attempting to control the maximum 
cell temperature below $40{ }^{\circ} \mathrm{C}$. An analysis was also performed on the heat transfer enhancement of cells, by increasing the number of mini-channels. They deduced the optimum number of channels as eight, based on cost of manufacturing and performance of the cooling system. No marginal effect is observed with alternating the inlet and outlet flow directions. To maintain overall cell temperature below $40{ }^{\circ} \mathrm{C}$ at higher discharge rates, micro channels are one of the effective ways.

Another passive cooling technique consists of incorporating batteries with phase change materials (PCMs) [15]. Less complexity of a design structure provides PCM an advantage over active cooling methods. PCMs act as heat sinks during discharging and store heat in the form of latent heat and later when the battery temperature drops, excess heat is released from the material. Exothermic reaction is possible due to the high latent heat capacity and thermal conductivity of the PCM. Mills et al. [16] enhanced thermal conductivity of PCMs through two orders of magnitude by impregnating porous graphite matrices with paraffin, thus making viable choice for thermal management of batteries. Heat pipe have an advantage over active cooling method (non-moving parts), hence it is extensively used in thermal management of electronic devices [17]. Heat pipes (length: $18 \mathrm{~mm}$ ) with wick size $0.9 \mathrm{~mm}$ were distributed evenly on the surface of the battery with a water cooled condenser section to keep the battery temperature $<50$ ${ }^{\circ} \mathrm{C}$.

\section{Modeling and simulation}

Along with advancements in cathode/anode materials for the LIBs, it is very critical to have high fidelity models. Accurate battery models are of paramount importance for EV applications to determine State of Charge (SOC), State of Health (SOH), miles per charge and ageing 
In recent years, extensive research has been carried out to understand EIS of LIBs and to comprehend looping at low frequencies, inductive tail at high frequencies and Warburg impedance line. Ozawa [21] carried out a study on key materials, cell construction, charge characteristics, discharge drain capability, temperature dependence of discharge capacity, cycle life, and safety characteristics of $\mathrm{C} / \mathrm{LiCoO}_{2}$ system. A noteworthy finding contributed by the article is a larger semi-circle in Cole-Cole plot at low frequencies, which is attributed by carbon anode, while smaller semi-circle is attributed by cathode surface area. Serrao et al. [22] modeled ageing of Ni-MH batteries for hybrid vehicles by using Thevenin's circuit. Series of pulse discharge load applied on battery lead to $2 \%$ drop in SOC. Open circuit voltage, other elements 
of Thevenin's model are determined by voltage characteristics of the load as detailed elsewhere [22].

Buller et al. [23] have demonstrated accuracy of non-linear, lumped equivalent circuit model of LIBs and super-capacitors by using EIS. Simulated results obtained from the equivalent circuit model are in good agreement with experimental data. Impedance of the system is strongly determined by SOC and temperature, therefore equivalent circuit model using impedance spectra is limited to only particular SOC and temperature. Chen et al. [24] adopted a novel run time based model to simulate polymer LIB and Ni-MH by neglecting the effect of self-discharge, cycle and temperature. Simulated results are in excellent coherence with experiments, showing error band of less than $0.4 \%$ and voltage response within $30 \mathrm{mV}$ for any load profile. A simple equivalent circuit model consisting of resistor in series with a parallel RC network accurately predicted the charge and discharge behavior of LIBs [25].

\section{Lifetime of automotive batteries}

A great concern for auto-makers with regards to EVs is the limitation of the automotive batteries. The battery pack has to be able to endure the rigors of daily use in an urban environment as well as maintain performance capability over the lifetime of the vehicle. Two influential parameters for a battery is capacity and power fade. These parameters show the amount of energy and power a pack can sustain over its lifetime. An article on cycling degradation of automotive LIBs sought to analyze these effects [26]. Tests that were reported in the article used a prismatic $\mathrm{LiFePO}_{4}$ battery that was cycled at $3 \mathrm{C}$ rate in intervals of 300 cycles. After every 300 cycle, characterization tests of capacity measurement, EIS, pulse discharge/charge, and urban dynamometer driving schedule (UDDS) driving cycle were implemented at different 
temperatures. During initial cycling, the results exhibited very low capacity and power fade. Temperatures above $50{ }^{\circ} \mathrm{C}$ have dominant effect after 600 cycles which increases both capacity and power fading. An interesting observation was that the batteries had substantially lower capacity and power fading at lower temperatures.

Capasso et al. [27] analyzed the performance of lithium based batteries for electric and hybrid EVs in contrast with $\mathrm{Pb}$-acid batteries. The three types of batteries tested were $\mathrm{LiFePO}_{4}$, $\mathrm{Li}[\mathrm{NiCoMn}] \mathrm{O}_{2}$ and $\mathrm{Pb}$-acid. They did a thorough analysis of each chemistry and tested their behaviors during a real automotive drive cycle. In this study, they used an urban scooter with battery packs connected in conjunction with an eddy current break coupled to an electric motor and the scooter was connected in a way to simulate road resistance. A specially designed flywheel was incorporated to provide inertia and the complete setup was done to simulate the forces a vehicle would produce on its battery pack. Results of this study demonstrated that the lithium based technology has the ability to uphold higher capacity, provide a more stable voltage profile and achieve higher driving ranges during dynamic driving operations compared to $\mathrm{Pb}-$ acid batteries.

Another study on complex ageing of high-power $\mathrm{LiFePO}_{4}$ cells at different C-rates was performed with six different cases to test the cells [28]. Cases one through three were to test symmetrical charge and discharge cycling of the cells at different temperatures; case four was to test symmetrical cycling at different SOCs at high temperatures; case five was to test the reaction of varying rest periods for cells before charge and discharge cycles and the last case was to test asymmetric cycling at diverse temperature ranges. It was concluded that battery ageing was 
strongly dependent on high temperatures and higher current rates for symmetric cycling, if a cell was at full SOC. It was also concluded that ohmic resistance was proportional to the total rest time of the batteries, and dependent on the type of cycling conditions. One of the main findings in the article was that the cells with lower SOC attained higher cycle life at higher temperatures compared to fully charged cells. The rest period of cells at any SOC or temperature level is hurtful to the life of the cell. On average, asymmetric charging and discharging was found to be detrimental to the health of the cell. Analysis on the lifetime estimation of $\mathrm{LiFePO}_{4}$ cells concluded that the chemistry would have a long calendar lifetime [29]. The cycle life is expected to reach as high as 8000 cycles at room temperature and power degradation between $3.27-5.59$ $\%$ was determined to be very low when under EVs drive cycles. Based on this observation, it was deduced that capacity fading would be the leading factor in loss of driving range compared to power fading for EVs.

\begin{abstract}
Another study was conducted on a simplified LIB lifetime model based on experimental Prius PHEV usage data for the repercussion of battery related wear to cost [30]. They determined the best conditions to charge an automotive battery to improve the degradation versus cost aspect in designing a vehicle. It was judged that charging during low electricity price intervals, having a low charge rate, charging at a low SOC and avoiding vehicle to grid applications ensured the best life to cost for the battery. The outcome of this study was to provide trends on improving the performance and lifetime of the battery and these results could be applied from smaller PHEV batteries to larger EV batteries. A good way to preserve the lifetime and health of the battery is by investing in a proper battery management system that monitors and tracks battery systems.
\end{abstract}




\section{Battery management systems}

Battery management system (BMS) plays a critical role in monitoring $\mathrm{SOC}, \mathrm{SOH}$ and estimating driving range of EVs. Performance of BMS is dependent on fidelity of battery model and is needed to respond to power demands based on driving patterns and road conditions. Li-ion based batteries have some apparent limitations which include varying capacity fade, degradation from excessive usage, thermal run-away and over charge/discharge. A well-designed BMS is critical to assure not only the safety and performance, but the longevity of LIBs as well. A BMS has several key functions encompassing cell protection, charge control, $\mathrm{SOC} / \mathrm{SOH}$ estimation and monitoring, cell-balancing, interface and so on. Cell protection is the most fundamental function of BMS to protect the battery from unfavorable operations and abuse out of the tolerance conditions. Once an overcharge or under discharge, a short circuit, or thermal runaway is detected, the BMS must automatically shut down the battery. IC manufacturers such as Texas Instruments, Linear Technology, Maxim Integrated and so on, who concentrate on the battery management applications can provide complete solutions to BMS designers including charging control, fuel gauge indication, monitor and protection.

For a BMS, SOC can provide precise estimation of battery life and the current capacity state of the cell to the user, which enables battery to perform the optimal charge or discharge profiles. Cheng et al.[31] focuses on the SOC development for EVs and a BMS is proposed in the article consisting of measurement of cell voltage, current, temperature, battery algorithm for $\mathrm{SOC} / \mathrm{SOH}$ estimation, cell-equalization, thermal management and other various functional modules. The SOC estimation from this model, which is further corrected by the Kalman filtering method, has been verified by conducting experiments on $\mathrm{LiFePO}_{4}$ batteries with extremely good agreement 
(98\%). In terms of over-temperature protection, positive temperature coefficient (PTC) resistors are typically used to prevent overheating in commercial LIBs. However, these external devices tend to fail when responding to fast thermal runaway. Chen et al. [32] dedicated to develop a fast and thermal-responsive polymer switching material consisting of graphene-coated spiky nickel nanoparticles mixed in a thin film with a high thermal expansion coefficient. Under abnormal conditions like overheating, the battery can be shut down rapidly by reducing the conductivity of electrodes, and the battery can resume the regular function spontaneously once the temperature becomes normal. The new material has $10^{3}-10^{4}$ times higher sensitivity compared to conventional devices.

For EV applications, the battery system normally contains thousands of single cells stacked in series or parallel to achieve high power capability. Tesla model S, one of the most popular EVs in the market, consists of 7, $104 \mathrm{Li}$-ion cells in 16 modules which provide the total power of 85 kWh [33]. However, in a multi-cell pack, even small differences between cells due to manufacturing and working conditions can be gradually magnified by imbalances between cells in the pack during charge and discharge cycles. An unbalanced cell could be driven to overcharge or under discharge which would prematurely age the cell and eventually lead to irreversible failure. All these factors make cell-balancing significant to the BMS. Typically, two different equalization methods are employed; passive and active. The passive method with no active control is applied to $\mathrm{Pb}$-acid and Ni-based batteries, while the active method can be implemented to LIBs. In a recent review article, Javier et al.[34] compared the main active cell balancing methods for most configurations including cell bypass, cell to cell, cell to pack, pack to cell and so on. For cell to cell, it was concluded that switching capacitors and double-tiered 
switching capacitors are the best options. A new structure of switching capacitors was investigated to increase balancing speed [35]. The literature analyzed the reason for slow speed of conventional switching capacitors and found that the cause is due to the energy transfer between near and far away cells. By using additional switches and capacitors, the proposed chain structure effectively overcomes the defect of conventional cell balancing circuit. Another consideration to BMS is the communication interface attached to external systems or devices. Controller Area Network (CAN) bus with two-wire configuration is the communication protocol for automotive systems. The combination of data and clock wires varies with components and devices [36]. There are various subsystems running in a modern vehicle like engine control, transmission, ABS, cruise control and BMS.

\section{Environmental and resource analysis}

As per the EPA report [37,38], ground transportation accounts for the second largest emission of $\mathrm{CO}_{2}$ followed by the electricity generation through fossil fuels in the United States. Hence EVs are being advocated to reduce greenhouse emissions significantly (see Figure 5) as the battery technology has better prospects and potential to reduce the demand on fossil fuels [39]. Vehicle architecture plays an important role in greenhouse gas emissions, parallel PHEV are favorable over series PHEV due to higher fuel economy and higher efficiency. Significant reduction in petroleum consumption is evident with plug-in EVs over ICEs and they widely vary based on the size of the car, driving and charging mode as studied by Bardley et al.[40]. Life cycle assessment is one of the ways to analyze environmental impacts and resources involved and extensively used in EV studies [41-43]. Thiel et al.[44] carried out a comparative study on cost, wheel to wheel analysis of $\mathrm{CO}_{2}$ production by gasoline, diesel, electric and hybrid vehicles for European market 
in the year 2010. Their analysis showed that the advanced ICEs emit highest $\mathrm{CO}_{2}$ of $160 \mathrm{~g} / \mathrm{km}$, whereas it is 145,88 and $60 \mathrm{~g} / \mathrm{km}$ for advanced diesel vehicles, PHEVs and EVs, respectively. Maclean et al.[45] have addressed issues on making light duty PHEVs more greener, especially on areas like extraction of raw materials, recycling and challenges associated with them. Environmental burden of electric mobility using LIBs ranging from Li- extraction, electrode production till the entire cell packing along with disposal of batteries were studied by Notter $e t$ al.[46]. They state that global warming potential index is higher for cathode and its collector than anode. It was concluded that LIB production has very negligible impact on environment while operation phase is the dominant source of environmental burden.

Samaras et al. [43] reported for the first time greenhouse gas emissions during battery production and detailed life cycle assessments on PHEVs, HEVs and conventional vehicles. Assessment is conducted by considering fuel economy of $30 \mathrm{mpg}$ for the case on conventional vehicle and 45 mpg for PHEVs and EVs. Average $\mathrm{CO}_{2}$ intensity produced by electrical grids is $920 \mathrm{~g} / \mathrm{kWh}$ for worst case during intensive loading on grid. In order to effectively reduce $\mathrm{CO}_{2}$ emissions, it is necessary to have paradigm shift toward carbon free electricity generation and battery operated vehicles [47]. Accelerated technological development in commercializing EVs operated using LIBs raises concern on the future demands of lithium reserves as well. Lithium deposits are found in the form of brines, pegmatites and sedimentary rocks and the largest source of brines is located at Atacama in Chile followed by China and Australia [48]. Pegmatite is another good source of lithium found in Australia, China and Zimbabwe [49]. Although Pegmatite constitutes higher Li concentration compared to brines, cost of production of lithium carbonate is relatively higher compared to brines [50]. Study states a $6 \%$ increase in the worldwide lithium production 
in the year 2014. Prices of lithium have fairly remained constant ranging from USD 1800-2000 per metric ton from 2011-2014, due to balanced increase in worldwide lithium consumptions [51]. Global lithium resources are reported ca. 39 million tons, but the projected demand for the period 2010-2100 is about 20 million tons as reported by Gruber et al.[50]. Wanger [52] raised warning on depletion of Li by 2020 with extensive demand of EVs and electronic devices in coming future and it appears that he is absolutely wrong. In order to evade surge in Li prices, efforts have to be made to recycle Li. Although Li- recycling will not prevent depletion of resources, efforts have to be made towards alternative energy sources like metal-air batteries, bioelectric batteries or hydrogen fuel cell operated vehicles.

\section{Futuristic energy systems}

The future of automotive energy systems will likely to be a blend of technologies such as fuel cells, ultra-capacitors/electrochemical capacitors, and LIBs with complimentary features of energy and power. With extensive research and development on the energy materials, the initial cost of the automotive system is becoming affordable, both in the battery and fuel cell operated vehicles (Tesla Model 3, Toyota Mirai and so on) [53]. Considering the fuel economy and the fuel prices, consumers can benefit from long-term ownership of EVs. There are two likely options of furthering the performance of futuristic energy storage devices. The first method is to continue research in advancing LIB chemistries that are well known, while the alternative method would be to invest the resources that are available into developing greater energy potential chemistries. Thackeray et al. [53] believed that the latter would provide the best results to develop Li metal based batteries such as Li-sulfur and Li-air. Currently, rechargeable aqueous and non-aqueous Li-air batteries have been paid lot of attention as they show larger specific energy compared to advanced LIBs [54]. However, they suffer from issues due to 
decompositions of the electrolytes and carbon electrodes during recharging at cell voltages higher than $4 \mathrm{~V}$. Further, the decomposition products lead to passivation of the air cathode and increase in polarization losses, ultimately limiting reversible formation and decomposition of the $\mathrm{Li}_{2} \mathrm{O}_{2}$ [55,56]. Liu et al.[57] demonstrated large capacity and highly efficient $\mathrm{Li}^{-} \mathrm{O}_{2}$ batteries using reduced graphene oxide electrode with LiI additive. The authors have demonstrated good cycle life with low capacity fading over a wider range of cycling rates.

Present, research and development efforts are focused on developing highly efficient and cost effective bi-functional air electrode materials. Na-ion batteries are also gaining momentum to replace LIBs owing to better safety, low cost, high abundance of Na metal. In order for the Naion batteries to become commercially viable, the development is required in materials level to improve the reversibility as well as enhancing the ionic conductivity of electrolytes $[58,59]$.

Theoretically, all metal based Lithium chemistries provide large energy densities compared to present LIBs, which is why they are very attractive for future EV applications. The problem that arises is the poor cycle life, lithium dendrite growth, lithium electrode deterioration from sulfur/oxygen, and hazards of working with lithium metal. Advancements are being made to remedy these problems by developing new types of electrolyte solvents like ether based technology [53]. As for future development, there are opportunities to use the growth of computing power to refine metal based battery chemistry along with experimental work. The cost reduction and the establishment of the infrastructure that can support these vehicles will depend on the market and the consumers. Trends discussed in other articles indicate the necessity to reduce the reliance on diminishing fossil fuel supplies, and cultural awareness of preserving the environment. 
Vehicle electrification patents could be a practical insight on what the possible future of automotive batteries in the market could turn out to be. An article has been written on finding patterns in EV mobility and they categorized their patent search in four section. These four categories are raw materials, cell components, battery system and vehicle [60]. It was taken into consideration that these four groups should have a convergence of automotive, chemical and electronics when filter the patents collected. In the last ten years, there has been an exponential trend in all four sections of patents with cell components being the highest. Within the four classifications, automotive and electronics make up more than $90 \%$ of EV related patents, and more than half of cell components and battery systems with a major focus on battery manufacturing towards automotive application. By looking at these patents, one can see the direction of battery technology in the market and how a good amount of these patents are in research and development. It appears that the trend of the battery future is towards the electrification of automotive applications. Evidently, the EVs and the PHEVs from various automakers use (or plan to use) advanced LIBs for meeting the EPA requirements at the affordable price. Table 2 consolidates the specifications of latest EVs, PHEVs and Hybrid with LIBs along with pricing (source: Respective Automaker's website).

\section{Second life usage}

Second life usage is where batteries serve in a new system, as they can no longer maintain the expected performance of the vehicles. Although, the second life battery applications are at the early stages of development, the market for second life batteries will most likely to grow proportionally with EV market because of the fact that retired automotive batteries can be gathered to supply second life needs. It should be vital that second life batteries are harnessed to 
support the ecosystem of electric utilities, off-grid energy, discount savings for consumers, and other tertiary systems that could use the battery [61]. There are many factors that influence second life batteries such as the SOHs, costs (new battery, repurposing and recycling) and so on. For example, the decision of when the battery pack should be retired depends on the range requirements and battery cost. As for second battery use in the utility sector, the possible cost savings can significantly be high for electric service power quality application. The other applications such as transmission support and long duration wind generation have also been reported to have appealing cost savings [62]. In addition, there are many opportunities for second life batteries in multitude of applications such as off-grid stationary photovoltaic systems, wind power, geothermal, hydroelectric and ocean energy systems [62,63]. As of now, the price of second life batteries could vary widely by region and by customer. Nevertheless, the price for second life batteries will stabilize when society sees the benefits and a system of organizing the cost saving has been incorporated into the utility system. It is expected that the utility applications for second life will grow exponentially with rapidly increasing EV deployments in the industrialized nations.

\section{Conclusion}

In order to attain the EPA fuel economy target, various types of vehicles including micro hybrids, mild hybrids, PHEV and EV with battery systems are available in the market. The review examined various battery systems based in the requirement for automotive applications and found the LIB system is the leader in performance, durability and safety. Even though the current cost of the LIBs is extremely high, the R\&D trend shows that it could significantly reduce to $\$ 100-200$ per $\mathrm{kWh}$. In addition, it is seemingly visible that the automotive LIBs can be used in various stationary applications living their second life, off-setting the initial costs. 


\begin{abstract}
Among various LIB chemistries, $\mathrm{LTO} / \mathrm{LiFePO}_{4}$ is most viable system considering cycle life and safety, even though they suffer with lower specific energy and power densities followed by LTO/ $\mathrm{LiCoO}_{2}$ based system, although they are expensive compared to other LIBs. From the economical and safety perspectives with fairly good electrochemical performance, $\mathrm{C} / \mathrm{LiFePO}_{4}$ would be the best candidate for PHEVs/HEVs applications. $\mathrm{LiMn}_{2} \mathrm{O}_{4}$ based chemistry offers high energy and power density but offers lower cycle life, lower thermal stability and safety. Table 3 summarizes overall performance characteristics of various LIBs based on practical energy density, cycle life and safety relevant for automotive applications. In order to achieve higher miles per charge, we would need battery system with at least 2-3 times higher energy density compared to current state of the art LIBs. Promising candidates to meet future energy density requirement would be $\mathrm{Li}-\mathrm{O}_{2}, \mathrm{Li} / \mathrm{S}, \mathrm{Li} /$ metal halides, however there still remains challenges to improve cycle life of these batteries [68].
\end{abstract}

Even though the LIBs are relatively expensive, they exhibit the highest energy along with longer cycle life. In addition, they have the possibility to incorporate smart battery management systems for improved safety. Hence it is projected that the LIBs will be able to meet 350 miles range by 2020 in EVs. Based on the current technology and the research trend, LIBs are the Panacea for the EV applications. 


\section{Acknowledgement}

The Authors would like to thank SRP, AZ for financial support. One of the authors (K.V) acknowledges NSF-Sri Lanka for offering an Overseas Fellowship (\# OSTP/2016/02) for visiting the Arizona State University during March-April, 2016. 


\section{References}

[1]Kim N, Moawad A, Shidore NS, Rousseau A. Fuel consumption and cost potential of different plug-in hybrid vehicle architectures. Argonne National Laboratory 2015.

[2]Bianchi D, Rolando L, Serrao L, Onori S, Rizzoni G, Al-Khayat N, Hsieh TM, Kang P. A rule-based strategy for a series/parallel hybrid electric vehicle: an approach based on dynamic programming. Proceedings of the ASME 2010 Dynamic Systems and Control Conference DSCC 2010, Cambridge, Massachusetts, USA.

[3]Recommended Electric Vehicle Charging Infrastructure Deployment Guidelines for the Greater Houston Area, October 2010, http://www.greenhoustontx.gov/ev/pdf/evdeploymentguidelines.pdf [accessed on April 1, 2016]. [4]Budde-Meiwes H, Drillkens J, Lunz B, Muennix J, Rothgang S, Kowal J, Sauer DU. A review of current automotive battery technology and future prospects. J. Automobile Engineering 2013;227:761-76.

[5] Dubaniewicz Jr. TH, DuCarme JP. Further study of the intrinsic safety of internally shorted lithium and lithium-ion cells within methane-air. J. Loss Prevention in the Process Industries 2014; 32:165-73.

[6]Dubaniewicz Jr. TH, DuCarme JP. Are lithium ion cells intrinsically safe?. IEEE Transactions on Industry Applications 2013;49:2451-60.

[7] Zaghib K, Dubé J, Dallaire A, Galoustov K, Guerfi A, Ramanathan M, Benmayza A, Prakash J, Mauger A, Julien CM. Enhanced thermal safety and high power performance of carbon coated $\mathrm{LiFePO}_{4}$ olivine cathode for Li-ion batteries. J. Power Sources 2012;219:36-44.

[8]Tesla Model S catches fire at supercharger in Norway, http://www.chicagotribune.com/classified/automotive/ct-tesla-fire-supercharger-norway 20160104-story.html; 2016 [accessed 16.01.04].

[9] Chevy Volt Gets New Support From Rogue Conservatives, Could Be Too Late To Save Car's Image, http://www.huffingtonpost.com/2012/03/31/chevy-volt-electric-car backlash_n_1392742.html; 2012 [accessed 16.03.31]. [10] Tesla Model S Bursts into Flames, Burns t a Crisp while Charging, http://www.zerohedge.com/news/2016-01-01/norwegian-car-b-q-tesla-model-s-bursts-flames burns-crisp-while-charging; 2016 [accessed 16.01.01]. [11]Mitsubishi reports fire in i-MiEV battery pack, melting in Outlander PHEV pack, http://www.greencarcongress.com/2013/03/mmc-20130327.html; 2013 [accessed 16.04.01]. [12] Car Fire a Test for High-Flying Tesla, http://www.nytimes.com/2013/10/04/business/car fire-a-test-for-high-flying-tesla.html?_r=0; 2013 [accessed 16.04.01]. [13]He F, Li X, Ma L. Combined experimental and numerical study of thermal management of battery module consisting of multiple Li-ion cells. International J. Heat and Mass Transfer 2014; 72:622-9.

[14] Zhao J, Rao Z, Li Y. Thermal performance of mini-channel liquid cooled cylinder based battery thermal management for cylindrical lithium-ion power battery. Energy Conversion and Management 2015; 103:157-65. [15] Al Hallaj S, Selman JR. A novel thermal management system for electric vehicle batteries using phase-change material. J. The Electrochemical Society 2000;147 (9): 3231-6.

[16]Mills A, Farid M, Selman JR, Al-Hallaj S. Thermal conductivity enhancement of phase change materials using a graphite matrix. Applied Thermal Engineering 2006; 26:1652-61. [17] Rao Z, Wang S, Wu M, Lin Z, Li F. Experimental investigation on thermal management of 

[18] Fotouhi A, Auger DJ, Propp K, Longo S, Wild M. A review on electric vehicle battery modelling: From Lithium-ion toward Lithium-Sulphur. Renewable and Sustainable Energy Reviews 2016; 56:1008-21.

[19] Samadani E, Farhad S, Scott W, Mastali M, Gimenez LE, Fowler M, Fraser RA. Empirical modeling of Lithium-ion batteries based on electrochemical impedance spectroscopy tests. Electrochimica Acta 2015; 160:169-77.

[20] Dubarry M, Liaw BY. Development of a universal modeling tool for rechargeable lithium batteries. J. Power Sources 2007;174:856-60.

[21]Ozawa K. Lithium-ion rechargeable batteries with LiCoO2 and carbon electrodes: the LiCoO2/C system. Solid State Ionics 1994; 69:212-21.

[22] Serrao L, Chehab Z, Guezennec Y, Rizzoni G. An aging model of Ni-MH batteries for hybrid electric vehicles. Vehicle Power and Propulsion 2005 IEEE Conference.

[23] Buller S, Thele M, De Doncker RWAA, Karden E. Impedance-based simulation models of supercapacitors and Li-ion batteries for power electronic applications. IEEE Transactions on Industry Applications 2005; 41:3.

[24] Chen M, Rincon-Mora GA. Accurate electrical battery model capable of predicting runtime and I-V performance. IEEE Transactions on Energy Conversion 2006; $21: 2$.

[25] Liaw BY, Nagasubramanian G, Jungst RG, Doughty DH. Modeling of lithium ion cells - A simple equivalent-circuit model approach. Solid State Ionics 2004; 175:835 - 39.

[26] Zhang Y, Wang CY, Tang X. Cycling degradation of an automotive $\mathrm{LiFePO}_{4}$ lithium-ion battery. J. Power Sources 2011; 196:1513-20.

[27] Capasso C, Veneri O. Experimental analysis on the performance of lithium based batteries for road full electric and hybrid vehicles. Applied Energy 2014; 136:921-30.

[28] Groot J, Swierczynski M, Stan AI, Kær SK. On the complex ageing characteristics of high power $\mathrm{LiFePO}_{4} /$ graphite battery cells cycled with high charge and discharge currents. J. Power Sources 2015; 286:475-87.

[29] Swierczynski M, Stroe DI, Stan AI, Teodorescu R, Kær SK. Lifetime estimation of the nanophosphate $\mathrm{LiFePO}_{4} / \mathrm{C}$ battery chemistry used in fully electric vehicles. IEEE Transactions on Industry Applications 2015; 51:3453-61.

[30] Hoke A, Brissette A, Smith K, Pratt A, Maksimovic D. Accounting for lithium-ion battery degradation in electric vehicle charging optimization. J. Emerging and Selected Topics in Power Electronics 2014; 2:691-700.

[31] Cheng KWE, Divakar BP, Wu HJ, Ding K, Ho HF. Battery-management system (BMS) and SOC development for electrical vehicles. IEEE transactions on vehicular technology 2011; 60:76-88.

[32] Chen Z, Hsu PC, Lopez J, Li YZ, To JWF, Liu N, Wang C, Andrews SC, Liu J, Cui Y, Bao ZN. Fast and reversible thermoresponsive polymer switching materials for safer batteries. Nature Energy 2016; 1:1-8.

[33] Tear down of $85 \mathrm{kWh}$ Tesla battery pack shows it could actually only be a $81 \mathrm{kWh}$ pack, http://electrek.co/2016/02/03/tesla-battery-tear-down-85-kwh/; 2016 [accessed 16.02.03]. [34]Gallardo-Lozano J, Romero-Cadaval E, Milanes-Montero MI, Guerrero-Martinez MA. Battery equalization active methods. J. Power Sources 2014; 246:934-49. 
[35] Kim MY, Kim CH, Kim JH, Moon GW. A chain structure of switched capacitor for improved cell balancing speed of lithium-ion batteries. IEEE Transactions on Industrial Electronics 2014; 61:3989-99.

[36] System management interface forum, Inc., SMBus specification version 3.020 Dec. 2014.

[37] Overview of Greenhouse Gases,

http://www3.epa.gov/climatechange/ghgemissions/gases/co2.html;2016 [accessed 16.02.24].

[38] Greenhouse gas emissions from a typical passenger vehicle, https://www3.epa.gov/otaq/climate/documents/420f14040a.pdf; EPA-420-F-14-040a (2014). [39] Pesaran AA, Markel T, Tataria HS, Howell D. Battery requirements for plug-in hybrid electric vehicles - analysis and rationale, 23rd International Electric Vehicle Symposium (EVS 23) Anaheim, California, December 2-5, 2007, NREL/CP-540-42240.

[40] Bradley TH, Frank AA. Design, demonstrations and sustainability impact assessments for plug-in hybrid electric vehicles. Renewable and Sustainable Energy Reviews 2009; 13:115-128. [41] Finnveden G, Hauschild MZ, Ekvall T, Guinee J, Heijungs R, Hellweg S, Koehler A, Pennington D, Suh S. Recent developments in life cycle assessment. J. Environmental Management 2009; 91:1-21.

[42] Orsi F, Muratori M, Rocco M, Colombo E, Rizzoni G. A multi-dimensional well-to-wheels analysis of passenger vehicles in different regions: Primary energy consumption, CO2 emissions, and economic cost. Applied Energy 2016; 169:197-209.

[43] Samaras C, Meisterling K. Life cycle assessment of greenhouse gas emissions from plug-in hybrid vehicles: implications for policy. Environ. Sci. Technol 2008; 42:3170-6.

[44] Thiel C, Perujo A, Mercier A. Cost and CO2 aspects of future vehicle options in Europe under new energy policy scenarios. Energy Policy 2010; 38:7142-51.

[45]Maclean HL, Lave LB. Life cycle assessment of automobile/fuel options. Environ. Sci. Technol. 2003; 37:5445-52.

[46]Notter DA, Gauch M, Widmer R, Wager P, Stamp A, Zah R, Althaus HJ. Contribution of Li Ion batteries to the environmental impact of electric vehicles. Environ. Sci. Technol. 2010;44: 6550-6.

[47]Campanari S, Manzolini G, Iglesia F. Energy analysis of electric vehicles using batteries or fuel cells through well-to-wheel driving cycle simulations. J. Power Sources 2009;186:464-77. [48] Lithium, http://www.indmin.com/Lithium.html\#/Prices; 2016 [accessed 16-03-30]. [49] Linnen RL, Lichtervelde MV, C`erný P. Granitic pegmatites as sources of strategic metals. Elements 2012; 8:275-80.

[50] Gruber PW, Medina PA, Keoleian GA, Kesler SE, Everson M.P, Wallington TJ. Global lithium availability: a constraint for electric vehicles? J. Industrial Ecology 2011;15:5: 760-75. [51]Jaskula BW. Lithium, U.S. Geological Survey, Mineral Commodity Summaries 2015, http://minerals.usgs.gov/minerals/pubs/commodity/lithium/mcs-2015-lithi.pdf.

[52] Wanger TC. The Lithium future - resources, recycling, and the environment. Conservation Letters 2011; 4:202-6.

[53] Thaceray MM, Wolverton C, Isaacs ED. Electrical energy storage for transportation approaching the limit of, and going beyond, lithium-ion batteries. Energy Environ. Sci. 2012;5:7854-63.

[54] Sunahiro S, Matsui M, Takeda Y, Yamamoto O, Imanishi N. Rechargeable aqueous lithium air batteries with an auxiliary electrode for the oxygen evolution. J. Power Sources 2014;262:338-43. 
[55]Wei ZH, Tan P, An L, Zhao TS. A non-carbon cathode electrode for lithium-oxygen batteries. Applied Energy 2014;130:134-8. [56] Cui ZH, Guo XX. Manganese monoxide nanoparticles adhered to mesoporous nitrogendoped carbons for nonaqueous lithium-oxygen batteries. J. Power Sources 2014;267:20-25. [57] Liu T, Leskes M, Yu W, Moore A, Zhou L, Bayley PM, Kim G, and Grey C P. Cycling $\mathrm{Li}_{-} \mathrm{O}_{2}$ batteries via $\mathrm{LiOH}$ formation and decomposition. Science 2015; 350: 530-533 [58] Seh ZW, Sun J, Sun Y, Cui Y. A highly reversible room-temperature sodium metal Anode. ACS Cent. Sci. 2015;1:449-55.

[59]Vignarooban K, Kushagra R, Elango A, Badami P, B. Mellander -E, Xu X, Tucker TG, Nam $\mathrm{C}$, Kannan AM. Current trends and future challenges of electrolytes for sodium-ion batteries. Int. J. $\mathrm{H}_{2}$ Energy 2016;41:2829-46.

[60 ]Golembiewski B, Stein N.V, Sick N, Wiemhofer HD. Identifying trends in battery technologies with regard to electric mobility: evidence from patenting activities along and across the battery value chain. J. Cleaner Production 2015;87:800-10.

[61] Neubauer J, Pesaran A. The ability of battery second use strategies to impact plug-in electric vehicle prices and serve utility energy storage applications. J. Power Sources 2011;196:10351-8. [62] Tong SJ, Same A, Kootstra MA, Park JW. Off-grid photovoltaic vehicle charge using second life lithium batteries: An experimental and numerical investigation. Applied Energy 2013;104:740-50.

[63] Debnath UK, Ahmad I, Habibi D. Quantifying economic benefits of second life batteries of gridable vehicles in the smart grid. Electrical Power and Energy Systems 2014;63:577-87. [64] Wang W, Choi D, Yang Z. Li-ion battery with $\mathrm{LiFePO}_{4}$ cathode and $\mathrm{Li}_{4} \mathrm{Ti}_{5} \mathrm{O}_{12}$ anode for stationary energy storage. Metallurgical and Materials Transactions A 2103; 44: 21-25.

[65] Stan AI, Świerczyński M, Stroe DI, Teodorescu R. Lithium ion battery chemistries from renewable energy storage to automotive and back-up power applications an overview International Conference on Optimization of Electrical and Electronic Equipment (OPTIM) IEEE $2014: 713-720$.

[66] Nitta N, Wu F, Lee JT, Yushin G. Li-ion battery materials: present and future. Materials today 2015;18: 252-264.

[67] Zaghib K, Dontigny M, Guerfi, Charest P, Rodrigues I, Mauger A, Julien CM. Safe and fast-charging Li-ion battery with long shelf life for power applications J. Power Sources 2011;196: 3949-3954. [68]Abraham KM. Prospects and limits of energy storage in batteries. J. Phys. Chem. Lett 2015; 6:830-844. 


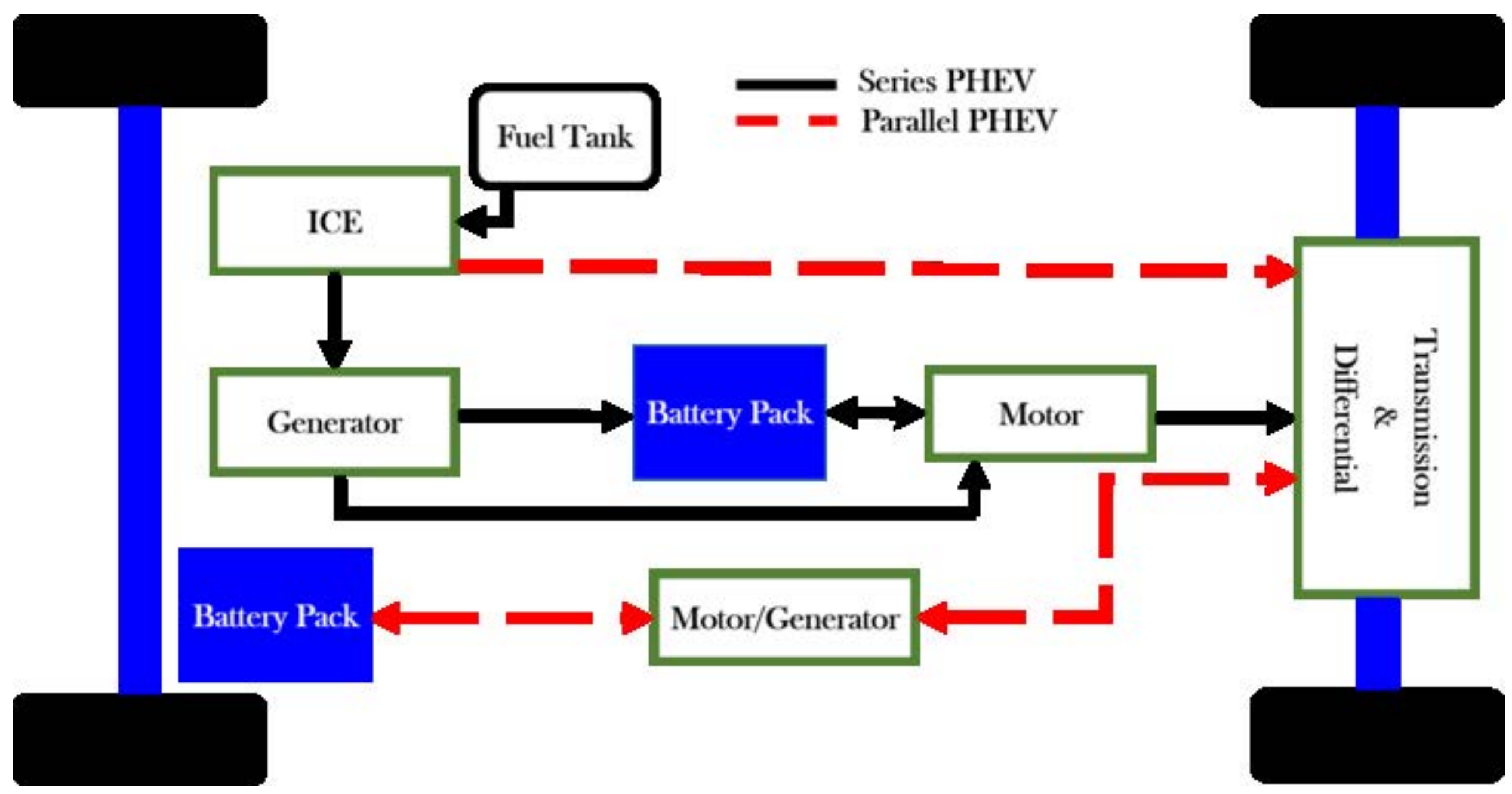




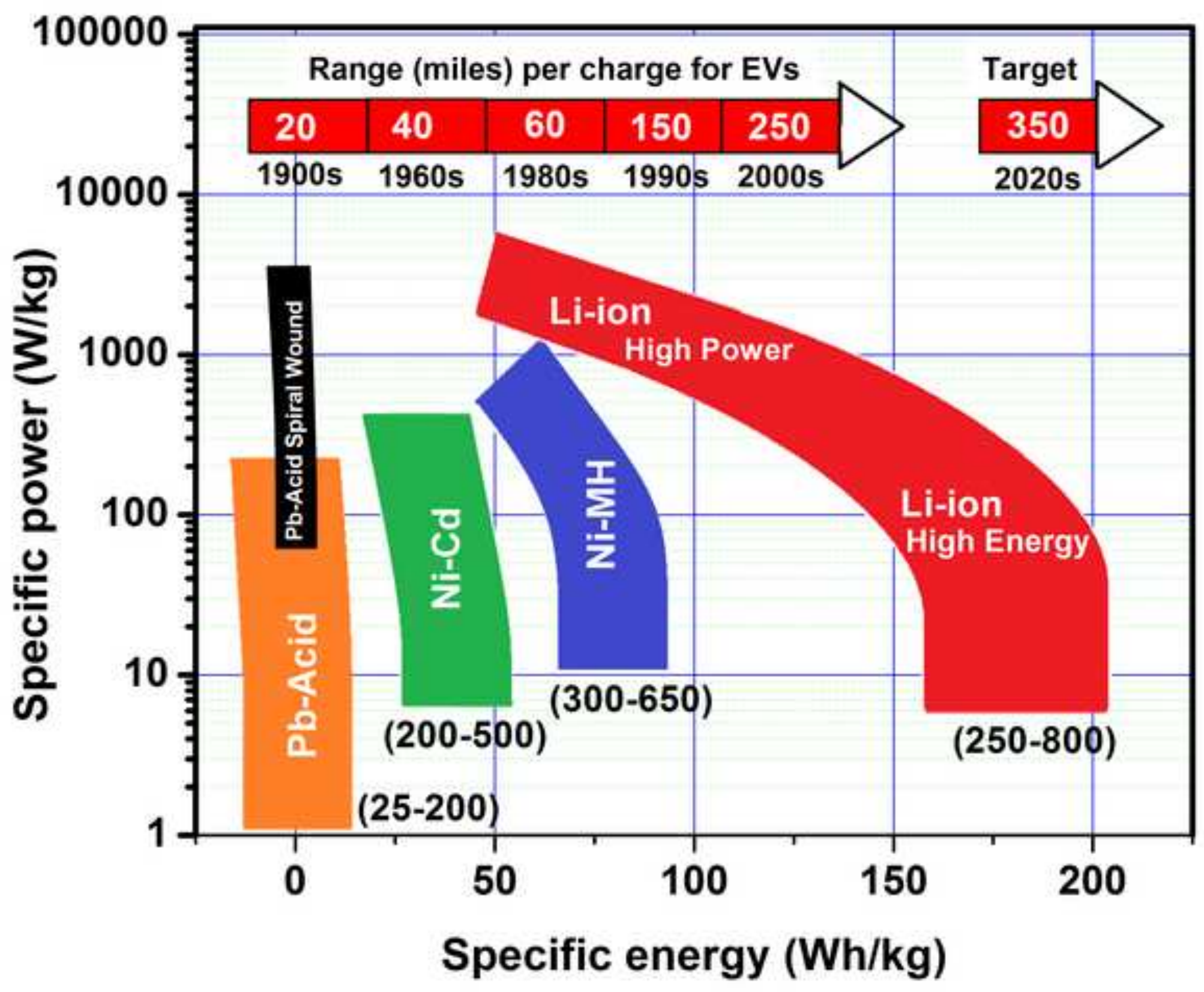



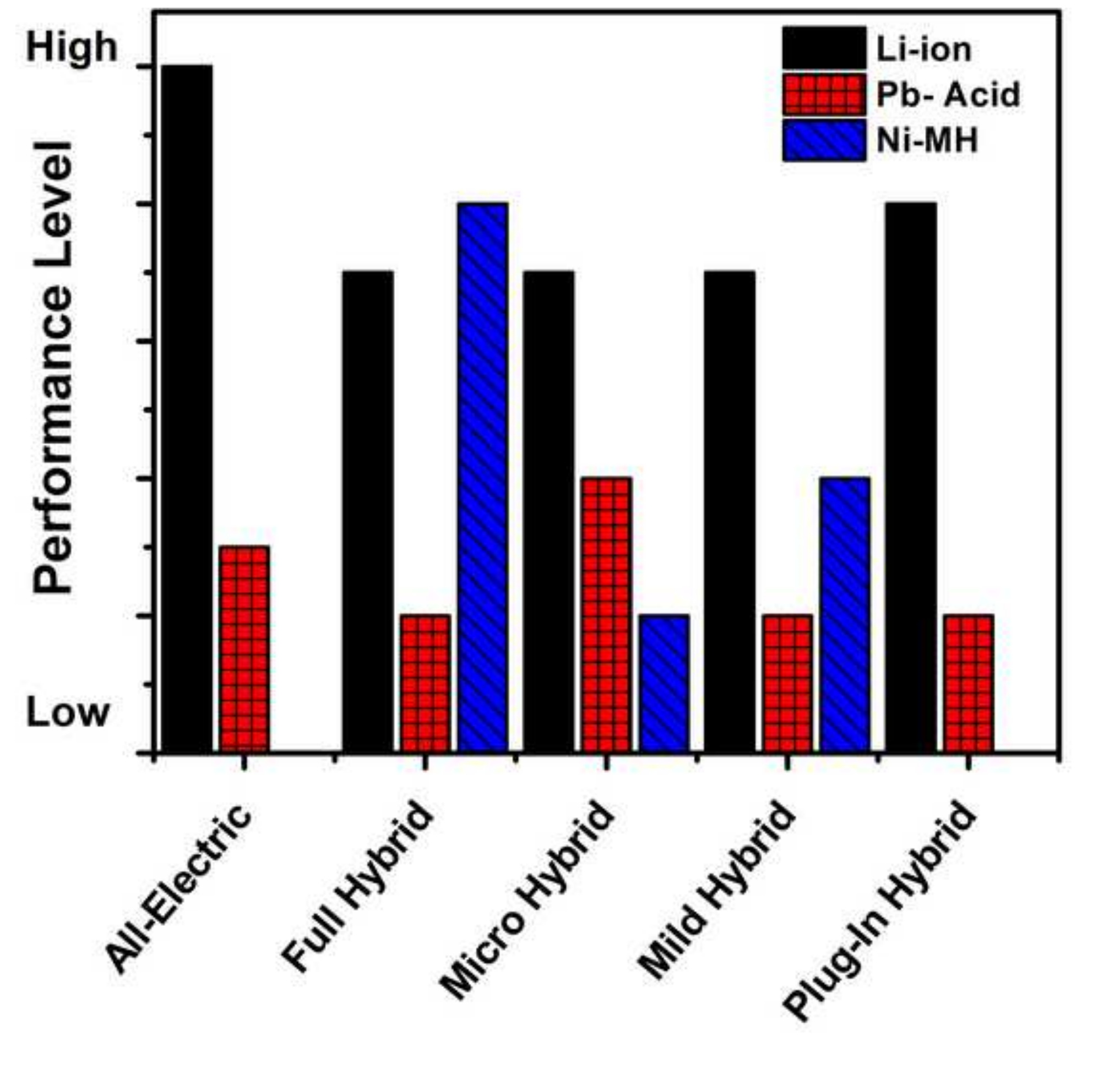


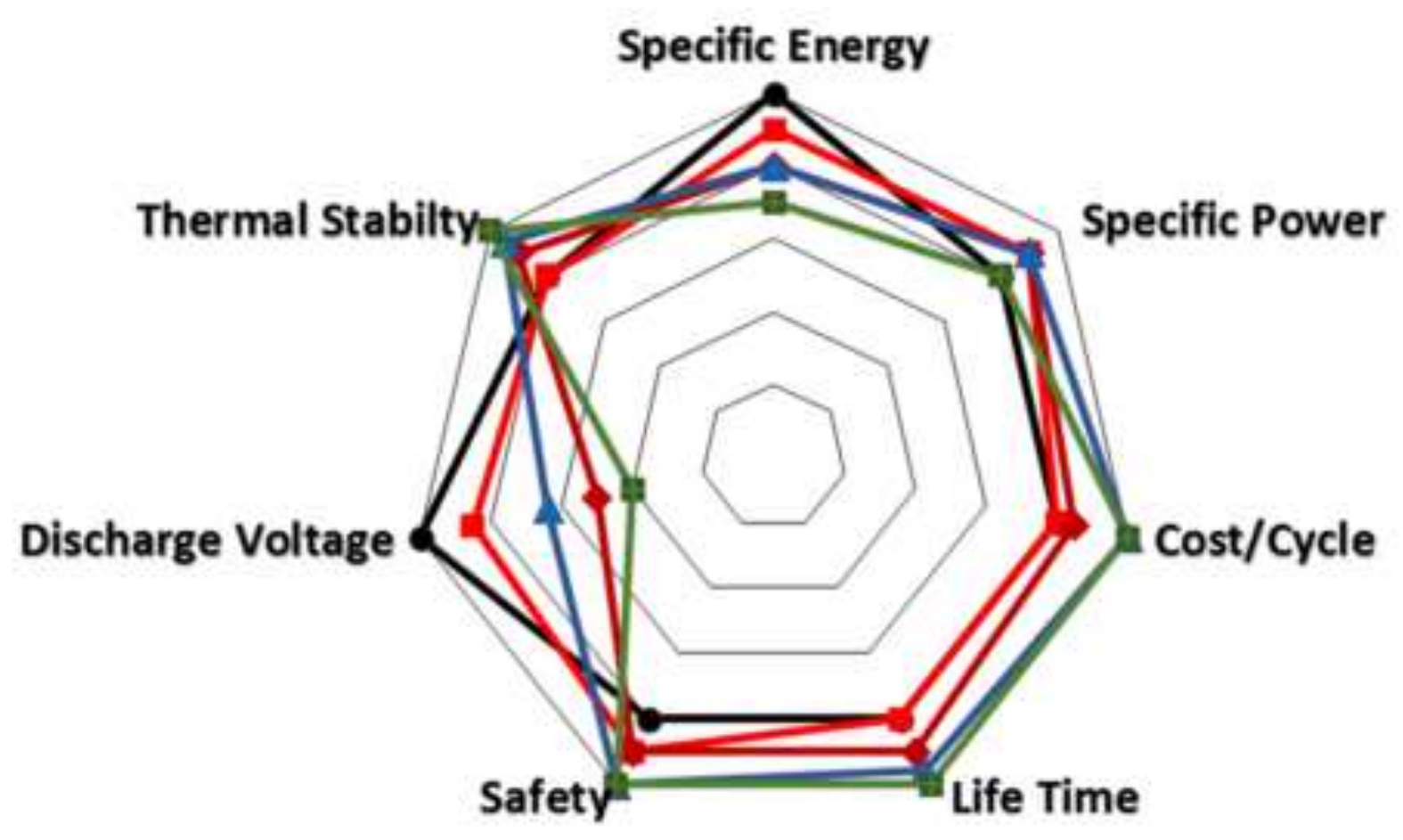

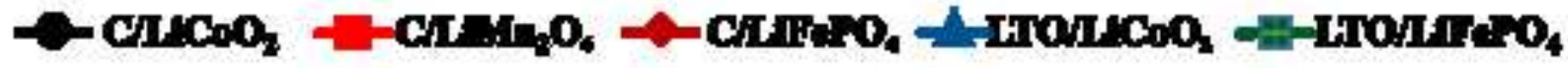




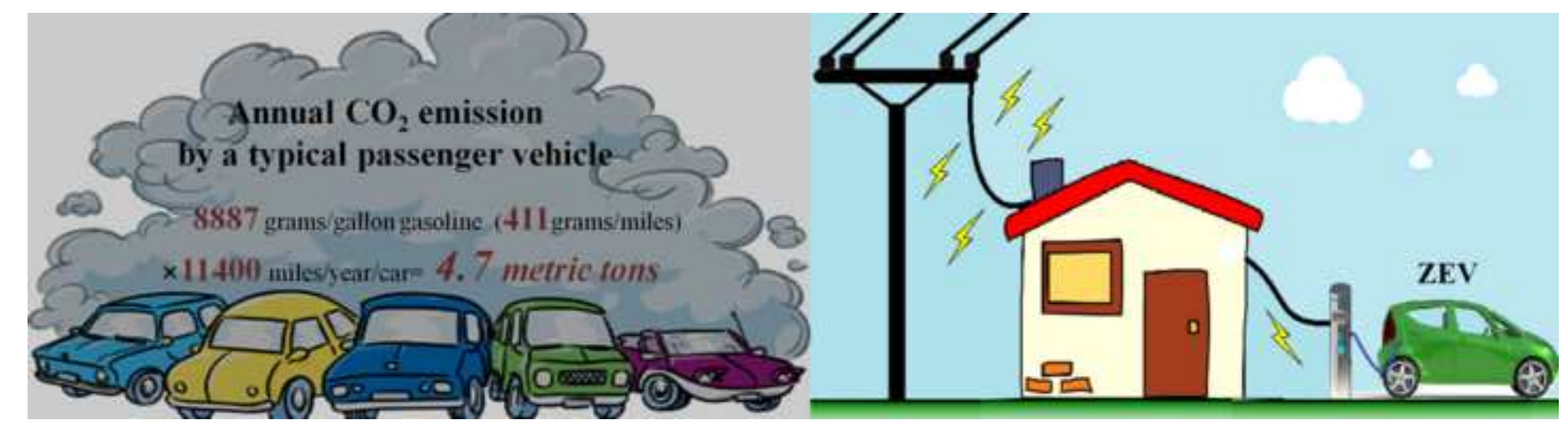


Table 1. Advantages and disadvantages of several modeling techniques for LIBs.

\begin{tabular}{|l|l|l|l|}
\hline Modeling Technique & \multicolumn{1}{|c|}{ Advantage } & Disadvantage & Reference \\
\hline $\begin{array}{l}\text { Equivalent Circuit } \\
\text { model }\end{array}$ & $\begin{array}{l}\text { Relatively simpler } \\
\text { Construction and lesser } \\
\text { computational time. }\end{array}$ & $\begin{array}{l}\text { Limited to only for } \\
\text { specific operating } \\
\text { conditions of the battery } \\
(100 \% \text {-SoC at RT })\end{array}$ & {$[18]$} \\
\hline $\begin{array}{l}\text { Mathematical Model } \\
\text { (Kinetic Battery } \\
\text { Model) }\end{array}$ & $\begin{array}{l}\text { Intuitive model, simpler } \\
\text { construction, easier to } \\
\text { determine rate capability } \\
\text { of the battery. }\end{array}$ & $\begin{array}{l}\text { Limited to only constant } \\
\text { charge and discharge } \\
\text { load, not accurate for } \\
\text { transient load. }\end{array}$ & {$[19]$} \\
\hline $\begin{array}{l}\text { Electrochemical- } \\
\text { Thermal model }\end{array}$ & $\begin{array}{l}\text { A physics based approach } \\
\text { involves set of coupled } \\
\text { electrochemical and } \\
\text { thermal PDEs, which are } \\
\text { solved numerically. } \\
\text { This model has high } \\
\text { accuracy and virtual } \\
\text { measurement of internal } \\
\text { state quantities is possible. }\end{array}$ & $\begin{array}{l}\text { Computationally } \\
\text { expensive. }\end{array}$ & {$[18]$} \\
\hline
\end{tabular}


Table 2. Specifications of EVs, PHEVs and Hybrid with LIBs.

\begin{tabular}{|c|c|c|c|c|c|c|}
\hline $\begin{array}{l}\text { Vehicle } \\
\text { Model }\end{array}$ & $\begin{array}{c}\text { Type } \\
\text { of } \\
\text { Vehicle }\end{array}$ & $\begin{array}{l}\text { Starting } \\
\text { Price of } \\
\text { Vehicle } \\
\text { (MSRP) }\end{array}$ & $\begin{array}{c}\text { Mile } \\
\text { Range } \\
\text { (mi) }\end{array}$ & $\begin{array}{c}\text { Miles per } \\
\text { Gallon } \\
\text { Equivalent }\end{array}$ & $\begin{array}{c}\text { Battery } \\
\text { Pack } \\
\text { Size } \\
\text { (kWh) }\end{array}$ & $\begin{array}{c}\text { Horsepower } \\
\text { (HP) }\end{array}$ \\
\hline $\begin{array}{l}\text { Nissan } \\
\text { Leaf } \\
(2016)\end{array}$ & $\mathrm{EV}$ & $\$ 29,010$ & 107 & $\begin{array}{l}126 \text { city, } \\
101 \\
\text { highway }\end{array}$ & $24-30$ & 107 \\
\hline $\begin{array}{c}\text { BMW i3 } \\
(2016)\end{array}$ & $\mathrm{EV}$ & $\$ 42,400$ & $\begin{array}{c}81,150 \\
\text { Range } \\
\text { Extender }\end{array}$ & $\begin{array}{l}137 \text { city, } \\
111 \\
\text { highway }\end{array}$ & 22 & 170 \\
\hline $\begin{array}{c}\text { Tesla } \\
\text { Model S } \\
(2015)\end{array}$ & $\mathrm{EV}$ & $\$ 69,900$ & $208-270$ & $\begin{array}{l}101 \text { city, } \\
102 \\
\text { highway }\end{array}$ & $60-85$ & $329-691$ \\
\hline $\begin{array}{c}\text { Tesla } \\
\text { Model } 3 \\
(2017 ?)\end{array}$ & $\overline{E V}$ & $\$ 35,000$ & $215-300 ?$ & & & \\
\hline $\begin{array}{c}\text { Hyundai } \\
\text { Sonata } \\
(2016)\end{array}$ & PHEV & $\$ 34,600$ & $\begin{array}{c}27 \\
\text { electric, } \\
600 \\
\text { combined }\end{array}$ & $\begin{array}{c}40 \text { city, } 44 \\
\text { highway }\end{array}$ & 9.8 & 202 \\
\hline $\begin{array}{c}\text { Chevrolet } \\
\text { Volt } \\
(2016)\end{array}$ & PHEV & $\$ 33,170$ & $\begin{array}{c}53 \\
\text { electric, } \\
420 \\
\text { combined }\end{array}$ & $\begin{array}{c}106 \\
\text { (electric), } \\
42 \text { (gas) }\end{array}$ & 18.4 & 149 \\
\hline $\begin{array}{l}\text { Toyota } \\
\text { Prius } \\
(2016)\end{array}$ & Hybrid & $\$ 24,200$ & $\begin{array}{c}11 \\
\text { electric, } \\
540 \\
\text { combined }\end{array}$ & $\begin{array}{c}54 \text { city, } 50 \\
\text { highway }\end{array}$ & 0.75 & 130 \\
\hline
\end{tabular}


Table 3. Performance characteristic of various LIB systems [64-67].

\begin{tabular}{|c|c|c|c|}
\hline Battery system & $\begin{array}{c}\text { Practical Energy Density } \\
(\mathbf{W h} / \mathbf{k g})\end{array}$ & Cycle life & Safety \\
\hline $\mathrm{C} / \mathrm{LiCoO}_{2}$ & $110-190$ & $500-1000$ & Poor \\
\hline $\mathrm{C} / \mathrm{LiMn}_{2} \mathrm{O}_{4}$ & $100-120$ & 1000 & Safer \\
\hline $\mathrm{C} / \mathrm{LiFePO}_{4}$ & $90-115$ & $>3000$ & Very safe \\
\hline $\mathrm{LTO} / \mathrm{LiCoO}_{2}$ & $70-75$ & $>4000$ & Extremely safe \\
\hline $\mathrm{LTO} / \mathrm{LiFePO}_{4}$ & $\sim 70$ & $>4000$ & Extremely safe \\
\hline
\end{tabular}

